\title{
1 Lipids and physical function in older adults
}

2 Patricia Casas-Agustench $^{\mathrm{a},{ }^{*},}$ Antonio Cherubini ${ }^{\mathrm{b}, *}$, and Cristina Andres-Lacueva ${ }^{\mathrm{a}}$

$4{ }^{a}$ Biomarkers and Nutrimetabolomic Laboratory, Department of Nutrition, Food Sciences and 5 Gastronomy, Food Technology Reference Net (XaRTA), Nutrition and Food Safety Research Institute

6 (INSA), Campus Torribera, Faculty of Pharmacy and Food Sciences, University of Barcelona,

7 Barcelona, Spain and ${ }^{b}$ Geriatrics and Geriatric Emergency Care, IRCCS-INRCA, Ancona, Italy

8 Correspondence to Professor Antonio Cherubini, Geriatrics and Geriatric Emergency Care, IRCCS-

9 INRCA, Ancona, Italy.

10 Tel: +390718003284; e-mail: a.cherubini@inrca.it

11 *Patricia Casas-Agustench and Antonio Cherubini contributed equally to the article. 
13 Healthy aging is a public health priority. The maintenance of adequate physical function is recognized

14 as a key element of healthy aging. In recent years, scientific evidence has increased concerning the 15 ability of lipids, in particular omega 3 polyunsaturated fatty acids (n-3 PUFAs), to positively 16 influence muscle and overall physical function in older patients. The article will critically review 17 observational as well as intervention studies on this topic, and it will elucidate the potential biological mechanisms underlying the beneficial effects of n-3 PUFA on physical function.

\section{Recent findings}

Observational studies and clinical trials performed in healthy older patients and in older patients with chronic diseases mostly found positive effects of n-3 PUFA on muscle metabolism, muscle strength and in general physical function.

\section{Summary}

24 Although the use of n-3 PUFA might represent an important intervention to preserve physical function in older adults, several key questions still need to be answered. Above all, large randomized controlled trials should be performed to confirm the utility of n-3 PUFA as therapeutic agents to prevent and treat physical function decline in old age.

\section{Keywords}

29 aging, lipid, n-3 polyunsaturated fatty acid, physical function, sarcopenia

\section{KEY POINTS}

31 - Physical function is a key component of healthy aging.

- n-3 PUFA supplementation has been shown in observational and intervention studies to improve muscle performance and physical function, mainly in healthy older people.

34 - Large-scale clinical trials are necessary to confirm that these beneficial effects can be obtained in the general older population, including patients with multimorbidity and frailty. 
Healthy aging is public health priority in our society [1]. The WHO report on aging and health defines healthy aging as 'the process of developing and maintaining the functional ability that enables wellbeing in older age', acknowledging that the ability to function is the most important aspect of health in the older population. Function can be viewed as a summary measure of the overall effect of agingrelated changes, lifestyle and diseases, in the context of the environment and social support. A great deal of attention is currently devoted to identify the determinants of healthy aging. Nutrition is considered one of the principal factors influencing aging-related and age-related diseases. Among nutrients, the role of proteins has been extensively investigated [2], whereas other substances, for example lipids, have received less consideration. Lipids are molecules whose biological functions include energy storage, signaling and acting as structural components of cell membranes. Recently, a number of studies investigated the potential role of lipids, in particular polyunsaturated fatty acids (PUFAs), in counteracting physical function impairment, which is often related to the loss of muscle mass and function with aging, that is sarcopenia, in older patients. In this review, we will critically examine the scientific literature on this topic and highlight areas that deserve further investigation.

\section{POLYUNSATURATED FATTY ACID AND PHYSICAL FUNCTION: OBSERVATIONAL}

\section{STUDIES}

PUFA contain more than one double bond. The most important PUFA are omega-3 (n-3) and omega-6 (n-6) PUFA. The former include alpha linolenic acid (ALA), eicosapentaenoic acid (EPA) and docosahexaenoic acid (DHA), whereas the latter include linoleic acid and arachidonic acid. ALA and linoleic acid cannot be synthetized by the human body and therefore are essential nutrients. Observational studies performed during the last decade suggest a potential role of n-3 PUFAs in the preservation of muscular and physical function in older adults $[3-8,9 \&-11 \&]$. Dietary intake of PUFAs in relationship to muscle and physical performance has been investigated in different populations. In the Hertfordshire study, Robinson et al. [3] estimated the average consumption of foods and assessed muscle function. In both sexes, the most important food positively associated with grip strength was fatty fish. In Japanese communitydwelling patients of 85 years of age a lower 
habitual intake of EPA and DHA was associated with poor functional mobility in men but not in women [7]. The higher proportion and severity of patients with cognitive impairment among women could explain this sex difference [7]. At variance, Rousseau et al. [5] found an association between self-reported dietary intake of n-3 PUFA and physical performance, which was not confirmed in the multivariable analysis. Another approach to examine the role of PUFA is to measure their levels in plasma $[4,6,8,9 \&-11 \&]$. Plasma FAs are good markers of dietary intake. These studies found a positive correlation between circulatory levels of n-3 PUFA and physical capacity measured as walking speed [4] and muscle strength $[4,10 \&]$ in older adults. In the InCHIANTI study, older patients with impaired lower extremity performance, defined as a short physical performance battery score less than 9, had lower plasma levels of total PUFA, n-3 and n-6 FAs. Moreover, participants who experienced a decline in physical performance during the follow-up had lower baseline levels of n-3 PUFA and higher n-6/n-3 ratio [4]. Similarly, in a population-based sample of French older adults, a higher percentage of long chain n-3 levels was associated with a lower probability to have reduced gait speed, whereas a higher ratio between arachidonic acid and n-3 PUFA in plasma was positively related to lower walking speed [9\&]. Finally, n-3 PUFAs were associated with larger muscle size and greater knee extensor strength [11\&] and prospectively with lower risk of mobility disability in women but not in men in a cohort study in Iceland [10\&]. No association was observed between plasma n-3 PUFAs or n-6 PUFAs and decline in gait speed [10\&]. The levels of long chain n-3 PUFA were significantly lower in cancer patients with sarcopenia [6]. The majority of observational studies found a relationship between long chain n-3 FAs and physical function, although some negative results have been reported and the association was not consistently found in both sexes. The relationship has been confirmed by direct measurement of levels of FAs, in longitudinal analysis with a long followup, and in different populations. Nevertheless, no study measured FAsmore than once, and therefore it is not possible to examine the relationship between changes in levels of FAs and modifications of physical function. The main characteristics of observational studies are described in Table 1. 
Clinical trials in healthy older patients $[12-15,16 \& \&, 17 \& \&, 18 \&]$ and in older patients suffering

91 from a chronic disease [19,20] have mostly demonstrated that n-3 PUFA improve muscle performance and physical function. Supplementation with $1.2 \mathrm{~g}$ /day of fish oil during 6-months in prefrail older women improved walking speed, but not hand grip or lower limb strength [14]. A recent study evaluated the effects of the supplementation of high doses n-3 PUFA (4 g/day) for 6 months, showing an improvement in muscle mass and performance in older adults [17\&\&]. In older women, fish oil supplementation increased resting metabolic rate, exercise-related energy expenditure, lean body mass and improved functional capacity [16\&\&]. On the contrary, some authors did not find any beneficial effects of n-3 PUFA on muscle mass, muscle strength and physical performance [15]. Positive results were also obtained in small clinical studies performed in older patients with different diseases. In patients suffering from chronic obstructive pulmonary disease, PUFA supplementation increased the effects of exercise training, in terms of peak exercise capacity and submaximal endurance time [19]. Few studies assessed the combined effect of exercise and n-3 PUFA. Overall, the effect of exercise training seems stronger than that of PUFA in increasing lean mass, muscle performance and physical capacity. Rodacki et al. [13] found that n-3 PUFA supplementation in combination with strength training significantly increased muscle strength and functional capacity gains compared with strength training alone in older women. However, n-3 supplementation alone before strength training did not have any effect [13]. At variance, resistance training increased muscle strength independent from the intake of PUFA, although an improvement in the skeletal muscle mass occurred only when it was combined with a healthy diet (with a n-6/n-3 ratio <2) [18\&]. As n-3 PUFAs improvemuscle strength, it could be assumed that they also increase muscle mass. However, intervention studies provided conflicting results on this aspect [21\&\&]. A likely explanation of this inconsistency might be the short duration of many trials and, in some of them, the insufficient amount of n-3 PUFA used, as it appears that a minimum dose of $2 \mathrm{~g}$ /day is needed to stimulate muscle anabolism. Furthermore, the method used to measure muscle mass is relevant: dual radiograph absorptiometry and bioelectrical impedance analysis assess whole lean body mass, only half of which is represented by muscle and might therefore be unable to detect small changes in muscular mass. The main characteristics of intervention studies are described in Table 2. 
The biological mechanisms by which PUFA improve muscular and physical function have been investigated but are not entirely clear yet. FAs have multiple functions at cellular level, being major components of membranes and being involved in several metabolic processes, by regulating the activity of enzymes and acting as signaling molecules. The available evidence suggests that n-3 PUFAs are active at muscular level, in which they could increase the synthesis and decrease the breakdown of proteins [22]. PUFAs seem to counteract the blunted anabolic response to stimuli, for example protein intake and exercise, the so-called anabolic resistance, which contributes to the occurrence of sarcopenia in older patients. In a seminal article, Smith et al. demonstrated that PUFAs stimulate protein synthesis not in the basal state but during hyperaminoacidemia and hyperinsulinemia condition. This activity was associated with an increased activation of the mechanistic target of rapamycin (mTOR) pathway [23]. The same authors investigated whether n-3 PUFA supplementation is able to increase the expression of genes involved in the regulation of mitochondrial function and anabolic pathways as well as decrease the expression of genes related to autophagy and atrophy of muscles $[24 \& \&]$. They found that several genes involved in respiratory electron transport and oxidative phosphorylation, that is mitochondrial function, were increased. At the same time, pathways involved in calpain-mediated and ubiquitin-mediated proteolysis, mRNA translation and inhibition of mTOR signaling were significantly decreased by n-3 PUFA. Overall, the changes observed were modest, suggesting that n-3 PUFA may induce small changes in the muscle 138 [24\&\&]. Interestingly, in animal models, n-3 PUFA have shown to reduce the rate of protein 139 degradation, likely by means of the inhibition of the nuclear factor kappa B (NF-kB) pathway [22]. 140 Other mechanisms have been proposed. When n-3 PUFAs are introduced, cell membranes of different 141 tissues including the skeletal muscle incorporate them. This fact has been shown in human studies $142[25,26]$. In addition, higher amounts of Ca2p-ATPase and Nap/Kp-ATPase proteins might explain 143 the increase in metabolic rate following n-3 PUFA ingestion [27]. n-3 PUFA may improve 144 mitochondrial functions by modulating nuclear gene expression and the mitochondrial membrane. In the nucleus, n-3 PUFA might affect the expression of genes regulating the energy metabolism and 
mitochondrial function such as the peroxisome proliferator-activated receptor gamma coactivator 1alpha [28\&]. In parallel, the activation of peroxisome proliferator-activated receptors (PPARs) may result in changes in energy metabolism by influencing mRNA, protein expression and the activity of various proteins. Furthermore, n-3 PUFA have been shown to increase the expression of genes involved in extracellular matrix organization, which are involved in the development and maintenance of the muscle [24\&\&]. The beneficial effect of PUFAs on the muscle and physical function could be explained in part by their anti-inflammatory properties [29]. First of all, they compete with n-6 PUFA, in particular arachidonic acid, as substrate for enzymes, such as cyclooxygenase and lipoxygenase that produce eicosanoids. Of note, the eicosanoids produced from n-3 PUFA are less powerful proinflammatory agents than those derived from arachidonic acid, and n-3 PUFAs are precursors of inflammation resolving molecules [29]. In this respect, it seems that the ratio of n-6 to n-3 PUFA in the diet might be important to reduce inflammation. Moreover, n-3 PUFA can decrease the synthesis of proinflammatory cytokines by binding to nuclear receptors. They prevent the degradation and subsequent translocation of the NF-kB complex to the nucleus in which it induces transcription of inflammatory cytokines. The reduction in NF-kB pathway activation is thought to be caused by an up-regulation in PPARg activity. In addition to direct action at the muscular tissue, n-3 PUFA could improve peripheral neuromuscular function, increasing muscle activation [30], nerve conduction velocity and the sensitivity to acetylcholine, which stimulates the contraction of the muscle [22].

\section{DISCUSSION}

The majority of studies found beneficial effects of n-3 PUFA intake and supplementation on muscle mass, muscle strength and physical function in older patients. Several mechanisms are likely to explain the ability of n-3 PUFA to improve physical function. The most consistent effects of n-3 PUFA supplementation is at the muscular level. First of all, they have a direct anabolic effect on the muscle that has been demonstrated also in older adults. n-3 PUFA might also reduce protein catabolism, although evidence in humans is limited. Mitochondrial function is enhanced by n-3 PUFA, through different actions. A large body of research supports an important anti-inflammatory 
activity of n-3 PUFA, but its contribution to the positive effects on the muscle has still to be confirmed in humans. Up to now, the majority of clinical trials did not find changes in inflammatory markers, possibly because they included relatively healthy older patients, whose level of systemic inflammation was normal. Nevertheless, also in prefrail older women n-3 PUFA did not modify the levels of inflammatory markers [14]. Finally, an improvement of neuromuscular function might occur during supplementation. Although the positive effects of n-3 PUFA have been confirmed in different trials, there are several limitations in the available scientific evidence. First of all, the majority of trials included relatively healthy older patients or patients with a specific chronic disease. It would be extremely relevant to confirm the possibility to improve muscle function and physical performance also in older adults who are suffering from multimorbidity, frailty and sarcopenia as the current therapeutic strategies for this group are limited, that is exercise and nutritional interventions, which consist of protein and vitamin D supplementation [31,32\&\&]. Moreover, it would be important to explore the potential benefits of n-3 PUFA in older patients who experience an accelerated muscle and functional loss, for example due to periods of forced immobilization. Although the optimal dose of n-3 PUFA is not known, the majority of clinical trials investigated the effect of moderate or high dose supplements of long chain n-3 FAs, that is doses equal or above $1 \mathrm{~g}$ /day of EPA and DHA. These doses are higher than those currently recommended for healthy patients. As the intake of n-3 PUFA is currently low in the majority of the population, the possibility to considerably increase the consumption of foods rich in long chain n-3 PUFA, that is fish, in particular fatty fish such as salmon, herring, halibut and mackerel, could be challenging. In this respect, supplementation might be the only effective strategy to achieve the desired intake. Another related but distinct issue is whether ALA, the precursor of long chain n-3 PUFA, might have similar effects on the muscle and on physical function. ALA, which is the most abundant n-3 FA in the Western diet, is present in vegetable oils and nuts, flax seeds and flaxseed oil, leafy vegetables and some animal fat. However, this question cannot be answered yet, as in the only study that evaluated a high dose of ALA supplement, the participants were also participating in a strength training program [18\&]. Although available data suggest that the effect of exercise on the muscle and on physical function is greater than that of n-3 PUFA, the combination of these two interventions has been tested in very few studies. All these 
201 points represent relevant topics that deserve further investigation. Finally, large-scale randomized 202 controlled trials need to be performed to evaluate whether n-3 PUFA treatment can postpone the onset 203 or slow the progression of physical function decline in older adults, using clinically relevant outcomes 204 in this population, such as the prevention or recovery of mobility disability [33\&].

206 The available evidence suggests that n-3 PUFA might be a promising treatment to prevent and treat 207 physical function impairment in older patients. However, large-scale clinical trials are needed to 208 confirm this hypothesis.

209 Acknowledgements

210 None.

211 Financial support and sponsorship

212 The authors are grateful for support granted by Spanish government grant from the Ministry of 213 Economy and Competitiveness (MINECO), the Joint Programming Initiative 'A Healthy Diet for a 214 Healthy Life' (JPI HDHL, website: http://www.healthydietforhealthylife.eu) on biomarkers MAPLE 215 (PCIN-2015-238) and the European Institute of Innovation and Technology (EIT) Health Programme 216 on Innovation by Design Cook2Health. We also thank the award of 2014SGR1566 from the 217 Generalitat de Catalunya's Agency AGAUR. This work was partially funded by the International Nut 218 and Dried Fruit Council Foundation (INC) in collaboration with the Bosch i Gimpera Foundation 219 (FBG307906). This work was also partly supported by a grant from the Innovative Medicines 220 Initiative (IMI-JU 115621).

\section{Conflicts of interest}

222 There are no conflicts of interest. 
Papers of particular interest, published within the annual period of review, have been highlighted as: $\&$ of special interest \&\& of outstanding interest

226

1. WHO. World report on ageing and health Geneva. Geneva: World Health Organization; 2015 ; Available at http://apps.who.int/iris/bitstream/10665/ 186463/1/9789240694811_eng.pdf. [Last accessed on 31 July 2016]

2. Bauer JM, Diekmann R. Protein and older persons. Clin Geriatr Med 2015; 31:327-338.

3. Robinson SM, Jameson KA, Batelaan SF, et al. Diet and its relationship with grip strength in community-dwelling older men and women: the Hertfordshire cohort study. J Am Geriatr Soc 2008; 56:84-90.

4. Abbatecola AM, Cherubini A, Guralnik JM, et al. Plasma polyunsaturated fatty acids and agerelated physical performance decline. Rejuvenation Res 2009; 12:25-32.

5. Rousseau JH, Kleppinger A, Kenny AM. Self-reported dietary intake of omega- 3 fatty acids and association with bone and lower extremity function. J Am Geriatr Soc 2009; 57:1781-1788.

6. Murphy RA, Mourtzakis M, Chu QS, et al. Skeletal muscle depletion is associated with reduced plasma (n-3) fatty acids in nonsmall cell lung cancer patients. J Nutr 2010; 140:1602-1606.

7. Takayama M, Arai Y, Sasaki S, et al. Association of marine-origin n-3 polyunsaturated fatty acids consumption and functional mobility in the communitydwelling oldest old. J Nutr Health Aging $2013 ; 17: 82-89$.

8. Welch AA, MacGregor AJ, Minihane AM, et al. Dietary fat and fatty acid profile are associated with indices of skeletal muscle mass in women aged 18-79 years. J Nutr 2014; 144:327-334

9. \& Frison E, Boirie Y, Peuchant E, et al. Plasma fatty acid biomarkers are associated with gait speed in community-dwelling older adults: the Three- City-Bordeaux study. Clin Nutr 2015. (in press). This is a cross-sectional and prospective study performed in a large sample of 
community-dwelling older patients that found an association between plasma n-3 fatty acids (FAs) and gait speed.

10. \& Reinders I, Murphy RA, Song X, et al. Polyunsaturated fatty acids in relation to incident mobility disability and decline in gait speed; the Age, Gene/Environment Susceptibility-Reykjavik Study. Eur J Clin Nutr 2015; 69:489-493. This is a prospective study in which long-chain n-3 polyunsaturated FAs (PUFAs) were associated with lower risk of mobility disability in women but not in men after 5 years of follow-up.

11. \& Reinders I, Song X, Visser M, et al. Plasma phospholipid PUFAs are associated with greater muscle and knee extension strength but not with changes in muscle parameters in older adults. J Nutr 2015; 145:105-112. This study found inconsistent cross-sectional associations between plasma phospholipid PUFAs and muscle parameters such as muscle size, intermuscular adipose tissue and strength.

12. Cornish SM, Chilibeck PD. Alpha-linolenic acid supplementation and resistance training in older adults. Appl Physiol Nutr Metab 2009; 34:49-59.

13. Rodacki CL, Rodacki AL, Pereira G, et al. Fish-oil supplementation enhances the effects of strength training in elderly women. Am J Clin Nutr 2012; 95:428-436.

14. Hutchins-Wiese HL, Kleppinger A, Annis K, et al. The impact of supplemental n- 3 long chain polyunsaturated fatty acids and dietary antioxidants on physical performance in postmenopausalwomen. J Nutr Health Aging 2013; 17:76-80. supplementation on body composition, muscle strength and physical performance in elderly individuals with decreased muscle mass. Int J Environ Res Public Health 2015; 12:10558-10574. and exercise metabolic rate in healthy community-dwelling older females. PLoS One 2015; 10:e0144828. This interventional study explored the effects of fish oil supplementation on resting 
metabolic rate, exercise-related energy expenditure, lean body mass and functional capacity in healthy community-dwelling older women.

17. \&\& Smith GI, Julliand S, Reeds DN, et al. Fish oil-derived n-3 PUFA therapy increases muscle mass and function in healthy older adults. Am J Clin Nutr 2015; 102:115-122. This is a double-blind, randomized controlled study that evaluated the effects of the supplementation of high doses of n-3 PUFA (4 g/day) for 6 months in healthy older people, showing an improvement in muscle mass and performance in older adults.

18. \& Strandberg E, Edholm P, Ponsot E, et al. Influence of combined resistance training and healthy diet on muscle mass in healthy elderly women: a randomized controlled trial. J Appl Physiol (1985) 2015; 119:918-925. This randomized controlled trial investigated the combined effect of resistance training and a healthy diet, with an n-6/n-3 ratio less than 2 .

19. Broekhuizen R, Wouters EF, Creutzberg EC, et al. Polyunsaturated fatty acids improve exercise capacity in chronic obstructive pulmonary disease. Thorax 2005; 60:376-382.

20. Sinn N, Milte CM, Street SJ, et al. Effects of n-3 fatty acids, EPA v. DHA, on depressive symptoms, quality of life, memory and executive function in older adults with mild cognitive impairment: a 6-month randomised controlled trial. Br J Nutr 2012; 107:1682-1693.

21. \&\& Smith GI. The effects of dietary omega-3s on muscle composition and quality in older adults. Curr Nutr Rep 2016; 5:99-105. A thorough review article summarizing the findings from the studies performed in older patients to evaluate the effects of n-3 PUFA on the muscle.

22. Jeromson S, Gallagher IJ, Galloway SD, Hamilton DL. Omega-3 fatty acids and skeletal muscle health. Mar Drugs 2015; 13:6977-7004.

23. Smith GI, Atherton P, Reeds DN, et al. Dietary omega-3 fatty acid supplementation increases the rate of muscle protein synthesis in older adults: a randomized controlled trial. Am J Clin Nutr 2011; 93:402-412. 
24. \&\& Yoshino J, Smith GI, Kelly SC, et al. Effect of dietary n-3 PUFA supplementation on the muscle transcriptome in older adults. Physiol Rep 2016; 4:e12785. This study used muscle biopsies to evaluate the effects of n-3 PUFA supplementation on the expression of genes involved in the regulation of mitochondrial function, anabolic pathways, autophagy and atrophy of the muscles.

25. Dangardt F, Chen Y, Gronowitz E, et al. High physiological omega-3 fatty acid supplementation affects muscle fatty acid composition and glucose and insulin homeostasis in obese adolescents. $\mathbf{J}$ Nutr Metab 2012; 2012:395757.

26. Herbst EA, Paglialunga S, Gerling C, et al. Omega-3 supplementation alters mitochondrial membrane composition and respiration kinetics in human skeletal muscle. J Physiol 2014; 592:13411352.

27. Hulbert AJ. Membrane fatty acids as pacemakers of animal metabolism. Lipids 2007; 42:811819.

28. \& Senoo N, Miyoshi N, Goto-Inoue N, et al. PGC-1alpha-mediated changes in phospholipid profiles of exercise-trained skeletal muscle. J Lipid Res 2015; 56:2286-2296. This research examined the influences of exercise training on phospholipid fatty acid composition in skeletal muscle and the molecular mechanisms of these influences, especially the role of the peroxisome proliferatoractivated receptor g coactivator $1 \mathrm{a}$.

29. Calder PC. Omega-3 polyunsaturated fatty acids and inflammatory processes: nutrition or pharmacology? Br J Clin Pharmacol 2013; 75: 645-662.

30. Lewis EJ, Radonic PW, Wolever TM, Wells GD. 21 days of mammalian omega-3 fatty acid supplementation improves aspects of neuromuscular function and performance in male athletes compared to olive oil placebo. J Int Soc Sports Nutr 2015; 12:28.

31. Pahor M, Guralnik JM, Ambrosius WT, et al. Effect of structured physical activity on prevention of major mobility disability in older adults: the LIFE study randomized clinical trial. JAMA 2014; 311: $2387-2396$ 
321 32. \&\& Bauer JM, Verlaan S, Bautmans I, et al. Effects of a vitamin D and leucineenriched whey 322 protein nutritional supplement on measures of sarcopenia in older adults, the PROVIDE study: a 323 randomized, double-blind, placebocontrolled trial. J Am Med Dir Assoc 2015; 16:740-747. This is a 324 randomized, controlled, double-blind, trial that investigated the effects of a vitamin D and leucine325 enriched whey protein oral nutritional supplement compared with an iso-caloric control supplement 326 on muscle mass and lower extremity function in sarcopenic older adults.

327 33. \& Cherubini ABR, Ferrucci L, Marchionni N, et al., editors. Clinical trials in older adults. Oxford, 328 UK: Wiley-Blackwell; 2015. This is the first book entirely devoted to describe the methodological 329 issues and challenges of performing clinical trials in older patients. 


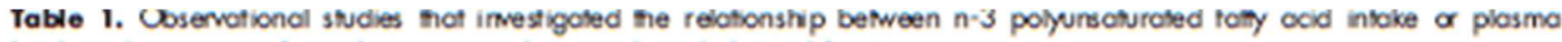
levels and mecosures of muscle moss, muscle strength and physical function

\begin{tabular}{|c|c|c|c|c|c|c|}
\hline Reforence & Study design & Population & $\begin{array}{c}\text { Age } \\
\text { (yoars) }\end{array}$ & $\begin{array}{l}\text { Sex distribution } \\
\text { \& female }\end{array}$ & $\begin{array}{l}\text { Somple } \\
\text { sixe }\end{array}$ & Moin results \\
\hline $\begin{array}{l}\text { Robinson of } \\
\text { of [3] }\end{array}$ & $\begin{array}{l}\text { Cross-soctiond and } \\
\text { rotrospoctiv } \\
\text { cohort study }\end{array}$ & $\begin{array}{l}\text { A large cohort of } \\
\text { community } \\
\text { dwoling olderly } \\
\text { indiniduals from } \\
\text { ho the fordshire } \\
\text { Cohot Study }\end{array}$ & $59-73$ & 47.4 & 2983 & $\begin{array}{l}\text { Highor fasy fish consumption } \\
\text { was associabd with highor } \\
\text { grip stongh }\end{array}$ \\
\hline \multirow[t]{3}{*}{$\begin{array}{l}\text { Abbctocola } \\
\text { of d. [4] }\end{array}$} & \multirow[t]{3}{*}{$\begin{array}{l}\text { Cross-soctiond and } \\
\text { prospective }\end{array}$} & \multirow[t]{3}{*}{$\begin{array}{l}\text { A populationbasod } \\
\text { study of older } \\
\text { tolians from the } \\
\text { hCHANTI study }\end{array}$} & \multirow[t]{3}{*}{$68.8 \pm 157$} & \multirow[t]{3}{*}{557} & \multirow[t]{3}{*}{$\begin{array}{l}1273 \\
\text { (basoline) } \\
884 \text { fat } \\
\text { followup) }\end{array}$} & $\begin{array}{l}\text { At basoline higher plasma in } \\
\text { PUFA concentations were } \\
\text { associatod with higher } \\
\text { walking speod }\end{array}$ \\
\hline & & & & & & 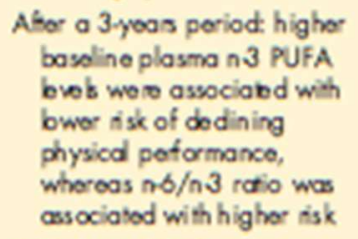 \\
\hline & & & & & & $\begin{array}{l}\text { A highor } \mathrm{m} 6 / \mathrm{h} 3 \text { ratio was } \\
\text { cssociatod with a longor } \\
\text { imo to walk } 7 \mathrm{~m} \text {, whoroas } \\
\text { sotal PUFA and n3 PUFA } \\
\text { were associatod with fas br } \\
\text { walking spood }\end{array}$ \\
\hline $\begin{array}{l}\text { Roussoav of } \\
\text { of [5] }\end{array}$ & Crosssoctiond & $\begin{array}{l}\text { Older odults } \\
\text { rosiding in the } \\
\text { community or an } \\
\text { cossistod living } \\
\text { focithy }\end{array}$ & $78.9 \pm 6.8$ & 52.2 & 247 & $\begin{array}{l}\text { Solf roportod n3 FA intoke } \\
\text { was associabd with } \\
\text { physiod poformance in the } \\
\text { univariate andysis bue the } \\
\text { cassociation was not } \\
\text { confimed in the multivaricto } \\
\text { andysis }\end{array}$ \\
\hline $\begin{array}{l}\text { Murphy of of. } \\
\text { [b] }\end{array}$ & Crosssoctiond & $\begin{array}{l}\text { Pationts with cancer } \\
\text { fom the nonsmdl } \\
\text { col lung cancer } \\
\text { cohort }\end{array}$ & $62 \pm 1.4$ & 53.6 & 41 & $\begin{array}{l}\text { Individuals with bw plasma or } \\
3 \text { PUFAs hod bwor musclo } \\
\text { mass and groater musclo } \\
\text { mass bss than individuds } \\
\text { with higher m3 PUFAs }\end{array}$ \\
\hline \multirow[t]{2}{*}{$\begin{array}{l}\text { Tokayoma of } \\
\text { of }[7]\end{array}$} & \multirow[t]{2}{*}{ Crosssoctiond } & \multirow[t]{2}{*}{$\begin{array}{l}\text { Japanose } \\
\text { community } \\
\text { dwelling oldest } \\
\text { old }\end{array}$} & \multirow[t]{2}{*}{$86-89$} & \multirow[t]{2}{*}{56.2} & \multirow[t]{2}{*}{495} & $\begin{array}{l}\text { A lowor habitud intake of } \\
\text { EPA + DHA was signticonty } \\
\text { cssociatod with poor } \\
\text { functional mobithy in mon } \\
\text { but not in women }\end{array}$ \\
\hline & & & & & & 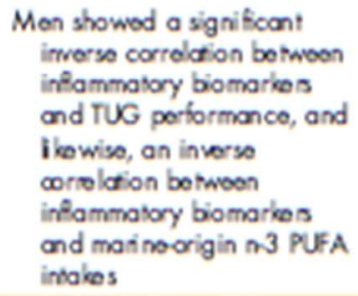 \\
\hline $\begin{array}{l}\text { Wolch of al. } \\
\text { [B] }\end{array}$ & Crosssoctichd & $\begin{array}{l}\text { Healthy frooliving } \\
\text { women from the } \\
\text { TwinsUK Srudy }\end{array}$ & $18-79$ & 100 & 2689 & $\begin{array}{l}\text { A higher PUFA so SFA ratio } \\
\text { was associabd with grocter } \\
\text { FM and FMI }\end{array}$ \\
\hline
\end{tabular}


Table 1 (Confinued)

\begin{tabular}{|c|c|c|c|c|c|c|}
\hline Reference & Study design & Population & $\begin{array}{c}\text { Age } \\
\text { (years) }\end{array}$ & $\begin{array}{l}\text { Sex distribution } \\
\% \text { female }\end{array}$ & $\begin{array}{l}\text { Sample } \\
\text { sixe }\end{array}$ & Moin results \\
\hline $\begin{array}{c}\text { Fisison of ol } \\
{\left[\varphi^{*}\right]}\end{array}$ & Crosssoctiond & $\begin{array}{l}\text { A Fronch } \\
\text { community } \\
\text { dwolling older } \\
\text { adults of the } \\
\text { ThrooCiny } \\
\text { Bordoaux study }\end{array}$ & 65 & 59.1 & 982 & 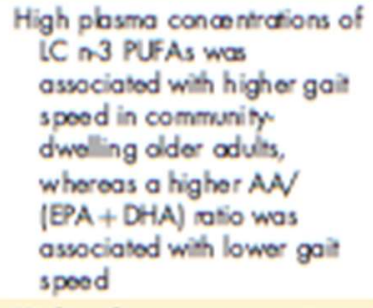 \\
\hline \multirow[t]{2}{*}{$\begin{array}{l}\text { Roindos of } \\
\text { d. [10*] }\end{array}$} & $\begin{array}{l}\text { Crossectiond and } \\
\text { prospective }\end{array}$ & $\begin{array}{l}\text { Oldor adults from } \\
\text { the Ago, Gone/ } \\
\text { Ervionmont } \\
\text { Suscoptbilly- } \\
\text { Reykjavk Study }\end{array}$ & $767 \pm 5.6$ & 53.6 & $\begin{array}{l}836 \text { kross. } \\
\text { soctional } \\
\text { andysis) }\end{array}$ & $\begin{array}{l}\text { Highor plasma concentutions } \\
\text { of PUFAs, ospocially EPA } \\
\text { and DHA, wore as sociatod } \\
\text { with brger muscle size and } \\
\text { groator knoe oxdonsion } \\
\text { stongh }\end{array}$ \\
\hline & & & $74.9 \pm 4.9$ & 54.3 & $\begin{array}{c}459 \\
\text { (prospectivo } \\
\text { andysis) }\end{array}$ & $\begin{array}{l}\text { Afor a } 5.2 \text { years period, av } \\
\text { lindonic acid was positivaly } \\
\text { associated with increasd } \\
\text { kneo eobension strength }\end{array}$ \\
\hline \multirow[t]{3}{*}{$\begin{array}{l}\text { Roindes of } \\
d .\left[11^{*}\right]\end{array}$} & Prospedive & $\begin{array}{l}\text { Older adults from } \\
\text { the Ago, Gono/ } \\
\text { Emvionmont } \\
\text { Suscoptbily- } \\
\text { Reykjavik Srudy }\end{array}$ & $75.1 \pm 5.0$ & 52.5 & 556 & $\begin{array}{l}\text { Highor plasma phospholipid } \\
\text { long-chain n } 3 \text { PUFAs, and } \\
\text { in patiaubr DHA, wore } \\
\text { associated with lower nisk of } \\
\text { moblly discbilly in women } \\
\text { but not in men afor 5-yoar } \\
\text { of folowup }\end{array}$ \\
\hline & & & & & & $\begin{array}{l}\text { No associaions wor } \\
\text { obsorved for plasma } \\
\text { phosphol pid bng-chain m } 3 \\
\text { PUFAs with doclino in gal } \\
\text { speed }\end{array}$ \\
\hline & & & & & & $\begin{array}{l}\text { Plasma phospholipid long } \\
\text { chain no PUFAs wore not } \\
\text { associatod with moblity } \\
\text { disability or doclino in gait } \\
\text { spood }\end{array}$ \\
\hline
\end{tabular}

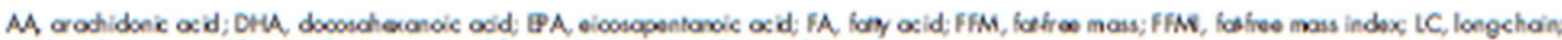
332

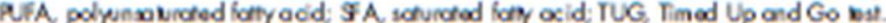




\section{TABLES}

Table 2. Interventional studies that investigated the effects of $n-3$ polyunsaturated folty acid on muscle mass and trength and physical function

\begin{tabular}{|c|c|c|c|c|c|c|c|c|}
\hline Roterence & Typo of study & Population & $\begin{array}{c}\text { Age } \\
\text { (years) }\end{array}$ & $\begin{array}{l}\text { Sox distribution } \\
\% \text { fomale }\end{array}$ & $\begin{array}{c}\text { Sample } \\
\text { sixe }\end{array}$ & $\begin{array}{l}\text { Study } \\
\text { dur otion }\end{array}$ & Intervention & Main results \\
\hline $\begin{array}{l}\text { Broolthizon } \\
\text { of d. [19] }\end{array}$ & $\begin{array}{l}\text { Doublo blind } \\
\text { randomizod tral }\end{array}$ & $\begin{array}{l}\text { Pationts with } \\
\text { COPD }\end{array}$ & $63 \pm 9$ & 437 & 102 & 8 wooks & 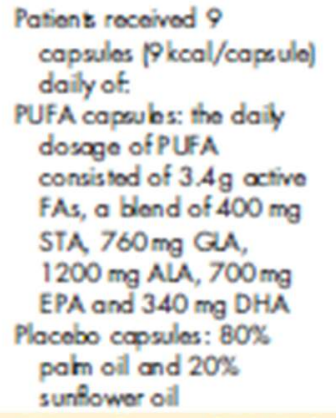 & 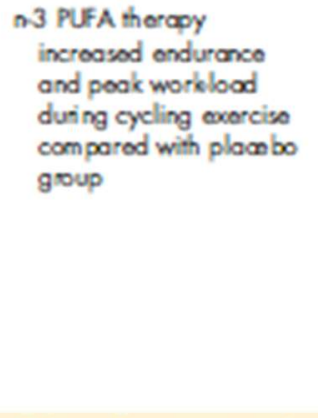 \\
\hline $\begin{array}{l}\text { Cornish and } \\
\text { Chilibock } \\
\text { [12] }\end{array}$ & $\begin{array}{l}\text { Randomized } \\
\text { controlod tid }\end{array}$ & $\begin{array}{l}\text { Hodthy oldbr } \\
\text { adults }\end{array}$ & $65.4 \pm 0.8$ & 45.1 & 51 & 12 wooks & 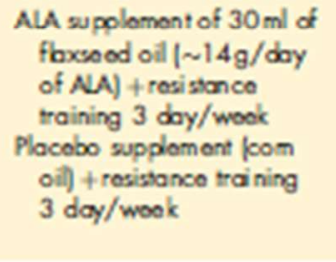 & $\begin{array}{l}\text { NA suppb montation with } \\
\text { resistance training } \\
\text { exposur resulod in only } \\
\text { minimal improvem ont of } \\
\text { loan tissu mass and } \\
\text { musdo strongth in } \\
\text { comparison with } \\
\text { resistance training done }\end{array}$ \\
\hline $\begin{array}{l}\text { Sinn of al. } \\
\text { [20] }\end{array}$ & $\begin{array}{l}\text { Doubloblind } \\
\text { random izod } \\
\text { controlod tidi }\end{array}$ & $\begin{array}{l}\text { Edotity } \\
\text { pooplo } \\
\text { with MCI }\end{array}$ & $>65$ & 32.0 & so & Gemonth & $\begin{array}{l}\text { EPArich FO: } 1.67 \mathrm{~g} \text { EPA + } \\
\text { O.16g DHA } / \mathrm{day} \\
\text { DHArich FO: } 1.55 \mathrm{~g} \\
\text { DHA + } 0.40 \mathrm{~g} \text { EPAday } \\
\text { SunBower all: } 2.2 \mathrm{~g} \text { UA (n6 } \\
\text { PUFA /day (oontoll) }\end{array}$ & $\begin{array}{l}\text { Inerocsod DHA was } \\
\text { significanty associatod } \\
\text { with improved solk. } \\
\text { roportod physionl hoolth } \\
\text { but not fundioning on } \\
\text { tho hodithy su woy SF.36 }\end{array}$ \\
\hline $\begin{array}{l}\text { Rodacle of al. } \\
\text { [13] }\end{array}$ & $\begin{array}{l}\text { Randomized } \\
\text { controlod tida }\end{array}$ & $\begin{array}{l}\text { Eldoty } \\
\text { momon }\end{array}$ & $64 \pm 1$ & 100 & 45 & $90-150$ days & 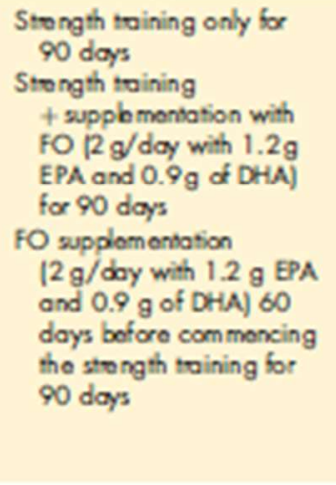 & 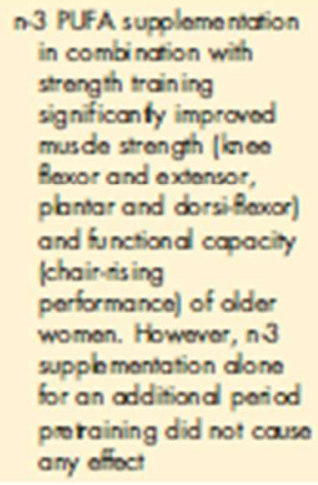 \\
\hline
\end{tabular}




\begin{tabular}{|c|c|c|c|c|c|c|c|c|}
\hline Reforence & Type of study & Population & $\begin{array}{c}\text { Age } \\
\text { (years) }\end{array}$ & $\begin{array}{l}\text { Sox distribution } \\
\text { \% fomale }\end{array}$ & $\begin{array}{l}\text { Sample } \\
\text { size }\end{array}$ & $\begin{array}{l}\text { Study } \\
\text { duration }\end{array}$ & Intervertion & Main results \\
\hline $\begin{array}{l}\text { Hutchins: } \\
\text { Wioss } \\
\text { of d. [14] }\end{array}$ & $\begin{array}{l}\text { Doubbblind, } \\
\text { randomizod } \\
\text { contolled trid }\end{array}$ & $\begin{array}{l}\text { Postmo } \\
\text { nopausd } \\
\text { womon }\end{array}$ & $75 \pm 7$ & 100 & 126 & benonh & 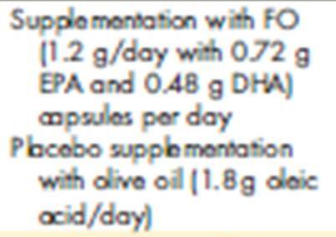 & $\begin{array}{l}\text { Supplomo nuction with FO } \\
\text { improvod waking spood } \\
\text { comparod with placobo, } \\
\text { but way inoffodive in } \\
\text { torms of muselo strongth }\end{array}$ \\
\hline $\begin{array}{l}\text { Smith of } d . \\
{\left[17^{* *}\right]}\end{array}$ & $\begin{array}{l}\text { Doubbblind, } \\
\text { randomizod } \\
\text { controlbd trid }\end{array}$ & $\begin{array}{l}\text { Hoalhy older } \\
\text { pooplo }\end{array}$ & $60-85$ & ND & 60 & 6enonh & $\begin{array}{l}\text { n3 PUFA tharapy that } \\
\text { provided a sotal of } \\
1.86 \mathrm{~g} \text { EPA and } 1.50 \mathrm{~g} \\
\text { DHA } \\
\text { P bcobo contol with corn } \\
\text { oll }\end{array}$ & 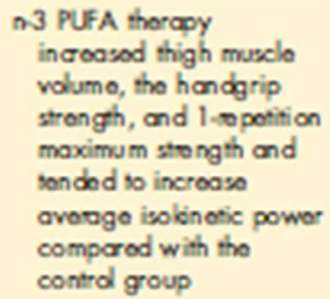 \\
\hline $\begin{array}{l}\text { logan and } \\
\text { Spriet } \\
{\left[16^{* *}\right]}\end{array}$ & $\begin{array}{l}\text { Randomi zod } \\
\text { controlbd trid }\end{array}$ & $\begin{array}{l}\text { Hoalhy } \\
\text { communiy } \\
\text { dwolling } \\
\text { oldor } \\
\text { womon }\end{array}$ & $66 \pm 1$ & 100 & 24 & 12 wooks & $\begin{array}{l}\text { FO supplamon bition: } 5 \mathrm{~g} / \\
\text { doy of FO }(2 \mathrm{~g} / \text { day } E \mathrm{AA} \\
\text { and } 1 \mathrm{~g} / \text { day DHWA } \\
\text { Pbcobo suppb mont: } 3 \mathrm{~g} / \\
\text { doy of olino oil }\end{array}$ & 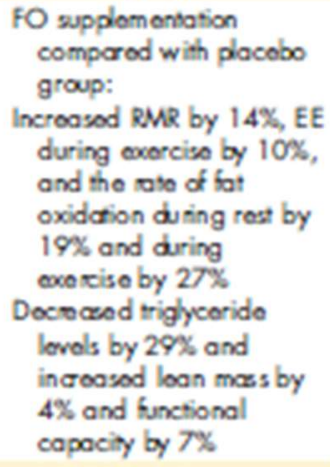 \\
\hline $\begin{array}{l}\text { Krzyminsib. } \\
\text { Siomaszoo } \\
\text { of d. [15] }\end{array}$ & $\begin{array}{l}\text { Randomizod } \\
\text { contolbd trid }\end{array}$ & $\begin{array}{l}\text { Eldorly } \\
\text { pooplo } \\
\text { with DMM }\end{array}$ & $74.6 \pm 8.0$ & 67.9 & 53 & 12 wooks & $\begin{array}{l}\text { PUFAtroatod groups } \\
\text { roceinod } 1.3 \mathrm{~g} \text { of } \mathrm{m} 3 \\
\text { PUFA. (2 capsulos daily } \\
\text { cntaining } 660 \mathrm{mg} \text { EPA, } \\
440 \mathrm{mg} \text { DHA }+200 \mathrm{mg} \\
\text { cher } 3 \text { FAs }+10 \mathrm{mg} \text { of } \\
\text { vitamin E) } \\
\text { Control groups rocoinod } 1 \\
\text { drop of vitamin E } \\
\text { solution (11 mg) daily }\end{array}$ & $\begin{array}{l}\text { m3 PUFA supplamentation } \\
\text { did not significontly } \\
\text { affoct body omposition, } \\
\text { musclo stongh or } \\
\text { physicol porformanco }\end{array}$ \\
\hline
\end{tabular}




\begin{tabular}{|c|c|c|c|c|c|c|c|c|}
\hline Reforence & Type of study & Population & $\begin{array}{c}\text { Age } \\
\text { (yoors) }\end{array}$ & $\begin{array}{c}\text { Sex distribution } \\
\text { \% fomalo }\end{array}$ & $\begin{array}{c}\text { Sample } \\
\text { size }\end{array}$ & $\begin{array}{l}\text { Study } \\
\text { duration }\end{array}$ & Intervertion & Main results \\
\hline $\begin{array}{l}\text { Strandborg } \\
\text { of ol [18\%] }\end{array}$ & $\begin{array}{l}\text { Thros armed } \\
\text { randomizod } \\
\text { contollod trial }\end{array}$ & $\begin{array}{l}\text { Hoalthy and } \\
\text { physically } \\
\text { activo } \\
\text { oldor } \\
\text { women }\end{array}$ & $65-70$ & 100 & 63 & 24 wooks & $\begin{array}{l}\text { Control group } \\
\text { A resistanco training group } \\
\text { A resistance training and } \\
\text { hoalthy dot group with } \\
\text { an no } / \mathrm{m} 3 \text { raso <2 }\end{array}$ & $\begin{array}{l}\text { Resistance training } \\
\text { improvod muselo strongth } \\
\text { Resistance training } \\
\text { combinod with a hedithy } \\
\text { diet (with a no/n } 3 \text { ratio } \\
<2 \text { ) improvod the } \\
\text { skobul muselo mass }\end{array}$ \\
\hline
\end{tabular}

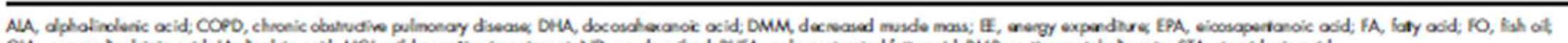

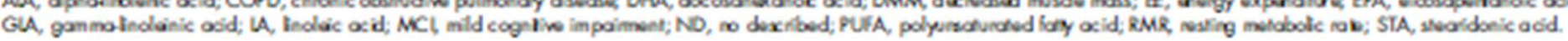

